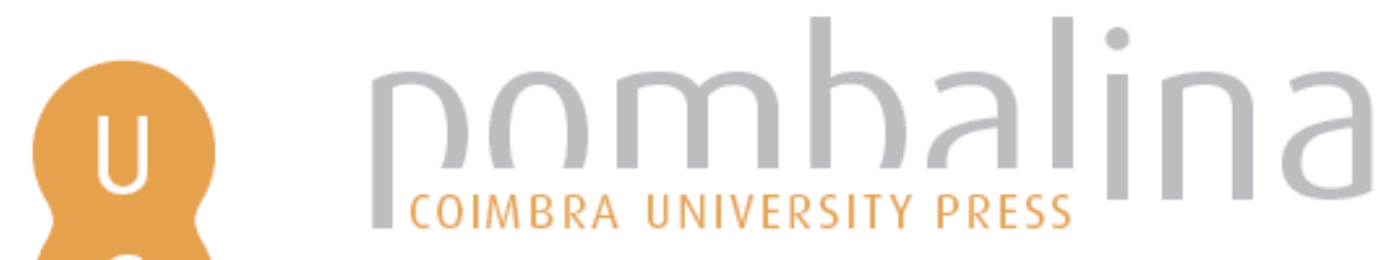

\title{
The jewel in the crown
}
Autor(es):
Brown, Susan Margaret; Honig, Edwin
Publicado por: Imprensa da Universidade de Coimbra
URL persistente:
URI:http://hdl.handle.net/10316.2/42361
DOI:
DOl:https://doi.org./10.14195/978-989-26-1308-6_47
Accessed : $\quad$ 26-Apr-2023 16:14:30

A navegação consulta e descarregamento dos títulos inseridos nas Bibliotecas Digitais UC Digitalis, UC Pombalina e UC Impactum, pressupõem a aceitação plena e sem reservas dos Termos e Condições de Uso destas Bibliotecas Digitais, disponíveis em https://digitalis.uc.pt/pt-pt/termos.

Conforme exposto nos referidos Termos e Condições de Uso, o descarregamento de títulos de acesso restrito requer uma licença válida de autorização devendo o utilizador aceder ao(s) documento(s) a partir de um endereço de IP da instituição detentora da supramencionada licença.

Ao utilizador é apenas permitido o descarregamento para uso pessoal, pelo que o emprego do(s) título(s) descarregado(s) para outro fim, designadamente comercial, carece de autorização do respetivo autor ou editor da obra.

Na medida em que todas as obras da UC Digitalis se encontram protegidas pelo Código do Direito de Autor e Direitos Conexos e demais legislação aplicável, toda a cópia, parcial ou total, deste documento, nos casos em que é legalmente admitida, deverá conter ou fazer-se acompanhar por este aviso.

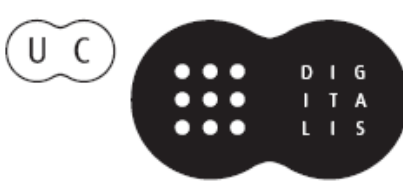





\section{THE JEWEL IN THE CROWN}

Susan Margaret Brown with posthumous contribution from Edwin Honig

I met Maria Irene in the Summer of 1982. My two years in Lisbon with a research grant from the Gulbenkian had come to an end, and I was looking for employment that would allow me to continue my research in Portugal. Edwin Honig, a friend to both of us, urged me to contact her. Perhaps she might hire me, he thought, to teach English in the Department of North American Studies. The prospect excited me, but nothing compared to what I felt upon arriving in Coimbra. A hike up the steep incline of meandering cobblestones brought me, exhilarated, to the top of the hill where the University stood splendid like a crown over the city. All that was left to do was look for Maria Irene. What I remember about that first meeting is the luminosity: the sunlight pouring through the tall office window, the fixed gleam in Maria Irene's steady gaze, the scintillating moments of conversation. Once we recognized our common interest in Pessoa and Whitman, our talk took leaps and dives like so many glistening fish. At one point, she even suggested that I design and teach a literature course. I left that day giddy with a sense of possibilities. I had received something so simple yet so precious. It's called inspiration: the direct, immediate kind that comes from spending time with somebody of Maria Irene's stature. 
The teaching experience gained over the next three years was invaluable. In addition to the full array of standard language courses, I managed to teach a course on persona theory, a course on Browning, Yeats and Eliot and the evolution of the dramatic dialogue, and a course on Walt Whitman. None of this would have been possible without Maria Irene's understanding of what a genuine academic community involves and her tireless efforts over decades to make the Department of American Studies at Coimbra a model of that vision. In this sense she is an enabler, someone who makes unexpected (and unexpectedly good) things happen. Not just for me but for whole generations of students who have had their lives transformed as a result of her exquisite literary training, expertise and unstinting giving of herself. Here is one brief example of Maria Irene in action. It was February, 1982. We had both been invited to give papers at the Pessoa Symposim at Vanderbilt University in Nashville, Tennessee. At the last minute I could not go. Maria Irene offered to take my paper and read it for me. At sunrise on the day before the conference I stood waiting in the Baixa near the bridge over the Mondego River. A taxi cab with Maria Irene in the back seat approached, stopped long enough for me to hand her my paper through an open window, then whizzed off, both of us still waving excitedly until the cab was completely swallowed up by the distance. Like a dream. Like a poem. Typical of moments spent with Maria Irene.

I know that this sentiment was also shared by Edwin, who always spoke glowingly of her. If he were alive today he most certainly would have wanted to contribute to this Homenagem for his dear friend. The piece below is a transcription of a dream that I recently found scribbled in faint pencil on a blank page at the back of Edwin's copy of The Poetry of John Donne and The Poetry of William Blake. ${ }^{1}$

\footnotetext{
${ }^{1}$ Edwin Honig's archive (papers, letters, journals, typescripts and manuscripts) is housed in the John Hay Library at Brown University in Providence, Rhode
} 
That it sounds like Pessoa should not surprise anyone, given Edwin's lifelong interest in translating him, but that the handwriting of the two is nearly identical borders on the uncanny.

They were people with large flat purple eyes or small black pen point eyes behind glasses that masked their real features, cheeks, chin, mouth, nose, as well as eyes. They were proud to think that this disguise helped them see more than others, but prouder that they really did not see anything more interesting than themselves as reflected on the inside of their glasses. He once said to me as he patted my shoulder, "You can tell you wear a mask though you don't wear glasses. How do you do it?" I said, "I see everything before it sees me." He laughed. "You lie: I have been watching you as you spoke." I said, "Thank you. You're right - but also wrong because I have never seen you before as you appear now, just having told me that. We are now both weak enough in each other's eyes to become good friends." At this, he made a burbling vulgar sound with his lips and stopped laughing. The last time I saw him he was going blind watching himself fascinated by the image of himself as a monocle dangling from a chain that bung from one eyelash.

Island. His private library of books is at the nearby college of Stonehill in Easton, Massachusetts. 